\title{
The right to an effective remedy in European law: significance, content and interaction
}

\author{
Wojciech Piątek ${ }^{1}$
}

Published online: 16 September 2019

(c) The Author(s) 2019

\begin{abstract}
One of the basic rights and a general principle of the European Union is the right to an effective remedy. In the paper is presented the basis of the right to an effective remedy derived from the first paragraph of Article 47. The right could be realized only before a tribunal which is an extraordinary public authority competent to adjudicate civil, criminal and administrative cases. The effectiveness of a remedy manifests itself in the sense of preventing the alleged violation of law or its continuation, or in providing adequate redress for any violation that had already occurred. The standard of the right to an effective remedy is fulfilled in all EU Member States differently. As an example in the paper was presented interactions between above mentioned standards and polish legal system in the area of administrative judiciary.
\end{abstract}

Keywords Effective remedy $\cdot$ European Law $\cdot$ Effective judicial protection · Access to a court $\cdot$ Administrative courts

\section{Introduction}

There is no doubt that basic rights are to a large extent put into practice collectively. For them to be effective, it is significant to understand their scope and to take these rights into account in the activity of European and domestic institutions. Above all, the basic rights have crucial importance for individuals who refer to the rights before public authorities. Therefore the basic rights remain under permanent legal interaction, which has many aspects and levels. ${ }^{1}$ This interaction takes place particularly between European and national courts, and even legislators.

\footnotetext{
1 Interaction between European and national courts occurs directly and indirectly. Direct dialogue takes place through the preliminary reference procedure. Indirect dialogue generally takes place through the process of adjudication. See more T. Tridimas (2015), The EJC and the National Courts: Dialogue, Cooperation and Instability, The Oxford Handbook of European Union Law, p. 404-405.
}

Wojciech Piątek

wojtekp@amu.edu.pl

1 Chair of Administrative and Court Administrative Procedure, Faculty of Law and Administration, Adam Mickiewicz University in Poznań, Al. Niepodległości 53, 61-714 Poznań, Poland 
One of the basic rights and a general principle of the European Union is the right to an effective remedy. The basis of this right is Article 47 of the Charter of Fundamental Rights of the European Union ${ }^{2}$ and Article 19 paragraph 1 of the Treaty on European Union, ${ }^{3}$ which guarantee individuals effective judicial protection in connection with high structural standards of independent tribunal established by law and procedural standards of an access and merits related adjudication of a dispute. According to the explanations relating to the Charter, ${ }^{4}$ the right from the first paragraph is strictly connected with Article 13 of the European Convention on Human Rights and Fundamental Freedoms. ${ }^{5}$ The second and the third paragraphs have their basis in Article 6 of the European Convention. Therefore for the determination of the standards of an effective remedy not only is the jurisprudence of European Court of Justice ${ }^{6}$ needed, but also European Court of Human Rights. ${ }^{7}$ The affinity of EU law with European Convention rights is close and the impact of the Convention is regarded as permeating and extensive. ${ }^{8}$ However, in EU law the protection is more extensive since it guarantees the right to an effective remedy before a court. In one of the first judgments devoted to this right, ECJ stated that all persons have the right to obtain an effective remedy in a competent court against measures which they consider to be contrary to the rights and freedoms guaranteed by the law of the Union. ${ }^{9}$ The remedy, which underlines the constitutional traditions common to the member states, must be able to cover the legality of the reasons for the contested decision, presupposing that the court to which the matter is referred may require the competent authority to notify its reasons. ${ }^{10}$ In that situation, for the effectiveness of the judicial review it has a crucial significance, that the competent authority should be obligated to respect a judgment in the future proceeding in the same case.

Article 47 applies to the institutions of the Union and of the Member States when they are implementing EU Law. The right to an effective remedy consists of many detailed rights derived from Article 47. First of all, the remedy should be effective. Secondly, the right should be fulfilled in a fair and public hearing, within a reasonable time, by an independent and impartial tribunal previously established by law. Lastly, an individual ought to have the possibility of being advised, defended and represented, also in the form of legal aid.

Because of the wide range of the above mentioned rights it would be difficult to present and research all of the guarantees in one paper. Each of the Member States has a wide margin of competence in interpretation of Article 47 and in creating their

\footnotetext{
2 Official Journal UE C 202 from 2016, p. 389.

3 Official Journal UE C 326 from 2012, p. 1.

4 Explanations relating to the Charter of Fundamental Rights, Official Journal of the European Union C 303/02 from 14 December 2007.

5 Dz.U. 1993, nb 61, poz. 284 as am., forth European Convention.

6 Hence forth ECJ.

7 Hence forth ECtHR.

8 T. Tridimas (2015), The EJC and the National Courts: Dialogue, Cooperation and Instability, The Oxford Handbook of European Union Law, p. 411.

9 ECJ, dec. of 15 May 1986, app. no 222/84-Marguerite Johnston v. Chief Constable of the Royal Ulster Constabulary, para. 19.

10 ECJ, dec. of 15 October 1987, app. no 222/86-Union nationale des entraineurs et adres techniques professionnels du football v. Georges Heylens and others, para. 14-15.
} 
own legal remedies. The legal construction should fulfill the guaranties of the right which is under control of ECJ.

This paper will present the basis of the right to an effective remedy derived from the first paragraph of Article 47 and an interaction between various standards of effective judicial protection in international and national legal systems. The main question to answer concerns the requirements which are necessary to evaluate a remedy as effective and in which way the law of European institutions affects national, above all Polish legal system. The term "effectiveness" has many connotations with the courts' adjudication and standards of protection of individual rights. Each of the above mentioned detailed rights derived from Article 47 of the Charter of Fundamental Rights of the European Union can be analyzed from a perspective of the effectiveness of the system of judicial remedies. The following reflections will be focused on the structural and procedural circumstances of the concept. An effective remedy should be accessible before a tribunal. The first question is also devoted to the circumstances which are necessary to regard a public authority to a tribunal or to a court power. The second question is concentrated on the scope of effectiveness of a remedy before a court. The last part compares selected aspects of the right to an effective remedy with the Polish legal system. This reflection will show the interaction between EU-law and a domestic legal order of one of the Member States.

\section{A tribunal as an authority to hear and adjudicate a remedy}

The right to an effective remedy could be realized only before a tribunal which is an extraordinary public authority competent to adjudicate civil, criminal and administrative cases. This authority should fulfill special structural and procedural requirements. In general, a court or a tribunal could mean an authority acting as a third party in relation to the authority which adopted the contested decision. ${ }^{11}$ A court must be organizationally independent from all parties of a dispute. This statutory independence should guarantee impartiality and objectivity in adjudicating. It would be impossible to ensure the standards if a court is engaged in a dispute or interested in an adjudication (nemo iudex in causa sua).

From the structural point of view, the court should not be linked in organizational and functional sense with administrative authorities. The structural basis of the legal position of the court should be ensured in constitution and in statues. Legal regulation on the judiciary at the constitutional and statutory level legitimizes the exercise by the courts of public authority. The courts which are created by legislator act not in their own name and interest, but in virtue of the will and competence granted by society. To fulfill their obligations legislator provide courts in special guarantees of independence towards executive power and legislative power.

Those guarantees of independence and impartiality have external and internal aspects. The first aspect entails that the body is protected against external intervention or pressure liable to jeopardize the independent judgment of its members with

${ }^{11}$ ECJ, dec. of 30 May 2002, app. no C 516/99-Walter Schmid, para. 34. 
regards to proceedings before them. ${ }^{12}$ In that sense a court must be a permanent public authority which is not under straight changes caused by other state authorities. The other authorities should not have a right to affect the court's activity in the area of jurisprudence. Both in theory and in practice it is hard to appoint a clear border between judicial and administrative court activities. ${ }^{13}$ Therefore in various countries regulations connected with appointment of new judges, judges salaries, transfers to another court and the end of professional activity are regulated differently. ${ }^{14}$ Especially in young democracies and in countries where the legal standards are not on a high level, is necessary to determine clear regulation about appointment and transfer of a judge from one court to the other. These regulations should have their source in constitutions. In other words, a judge should have a certainty, that his decisions will not affect his privacy and social status.

The second aspect, which is internal, is linked to impartiality and seeks to ensure a level playing field for the parties in the proceedings and their respective interests in relation to the subject matter of those proceedings. ${ }^{15}$ This aspect requires objectivity and the absence of any interest in the outcome of the proceedings apart from the strict application of the rule of law. ${ }^{16}$ The internal aspect is also strictly connected with personal characteristics of a judge who must be impartial in his intellect and fair in passing judgments. ${ }^{17}$ In that sense, a judge should not be susceptible to external influences. This aspect depends on each judge who should create his own internal guaranties of independence and impartiality. A creation of this features is in the interest of whole society who should help the judicial power to obtain a high level of independence. For each member of a society it has a crucial importance to be judged by impartial judges.

From the external aspect, this standard requires rules, particularly as regards the composition of the body and the appointment, length of service and the grounds for abstention, rejection and dismissal of its members, in order to dismiss any reasonable doubt in the minds of individuals as to the imperviousness of that body to external factors and its neutrality with respect to the interests before it. ${ }^{18}$ In order to consider the condition regarding the independence of the body making the reference as met, case-law requires, inter alia, that dismissals of members of that body should

\footnotetext{
12 ECJ, dec. of 31 January 2013, app. no C 175/11-H.I.D. B.A. v. Refugee Applications Commissioner and others, para. 96-97.

13 Voßkuhle and Sydow (2002), p. 677, Grabenwarter and Pabel (2016), p. 489-490.

14 For example, in many European countries a special judicial council has a great importance in the process of appointing of new judges. See: Garoupa and Ginsburg (2009), p. 106-113. An exception from this is the legal order in Czechia, where the autonomy of judicial system is guaranteed by a high position of courts presidents. See Kosař (2017), p. 105-110.

15 ECJ, dec. of 31 January 2013, app. no C 175/11-H.I.D. B.A. v. Refugee Applications Commissioner and others, para. 96-97.

16 ECJ, dec. of 19 September 2006, app. no C 506/04-Graham J. Wilson v. Ordre des advocates du barreau de Luxembourg, para. 52.

17 This aspect can not be guaranteed in constitutions or statues. It depends on personal characteristic of each judge. See Papier (2001), p. 1091.

18 ECJ, dec. of 4 February 1999, app. no C-103/97-Josef Köllensperger GmbH Co. KG and Atzwanger AG v. Gemeinverband Bezirkskrankrenhaus Schwaz, para. 20-23.
} 
be determined by express legislative provisions. ${ }^{19}$ A judge should function in such structural circumstances which could guarantee him preservation of impartiality and freedom in adjudication. On this basis a judge can build his internal impartiality.

The internal aspect is strictly linked with procedural circumstances of the impartial and competent court. One of the procedural institutions which ensure neutrality of the court is disqualification of judges. In Polish Law on Proceedings Before Administrative Courts $^{20}$ the conditions for disqualification of a judge from a proceeding are divided into two parts. In the first group, a judge is disqualified from performing their office in a concrete case by the operation of law. Special conditions leading to a disqualification of a judge from a proceeding in a concrete case are mentioned in the Law on Proceedings Before Administrative Courts, ${ }^{21}$ Article 18 NB 3. The conditions depend on the attitude of the judge towards the parties of the proceeding or towards the case which is adjudicated. ${ }^{22}$ Disqualification of a judge taking part in adjudication causes nullification of the proceeding, taken into account at each stage of the procedure before administrative courts. It is also a condition for reopening the proceeding which was ended by a binding and final judgment.

The second part of the conditions of disqualification of a judge has a more general nature. On the one hand, a judge shall be disqualified from a proceeding because of circumstances of such a kind that would give rise to justified doubts as to his impartiality in the case. The judge itself should have an additional internal conviction that the judgment can be passed without favoring any party to the proceedings. ${ }^{23}$ On the other hand, the lack of the judge's impartiality should not be measured by the level of just and kindness shown to the parties at the hearing. Doubt as to the impartiality of the judge can not be only supposed, apparent but real. Otherwise, the unique legal character of the institution of exclusion of a judge would be denied.

A disqualification is not effected by the operation of law, but by a court's order. An issuing of this act should be preceded by a discovery proceeding in which a necessity of judge disqualification will be confirmed. ${ }^{24} \mathrm{~A}$ party of a proceeding has not a right to disclose a judge from adjudication, but a right to hear a case by an impartial judge.

From a procedural point of view, for the existence of a court the course of the proceeding itself is significant. Article 47 treats about a fair and public hearing. During the procedure both sides of the dispute should have a possibility to present and defend their statements. An effective judicial protection comprises the principle of

\footnotetext{
19 ECJ, dec. of 17 September 1997, app. no Case C-54/96-Dorosch Consult Ingenieurgesellschaft mbH v. Bundesbaugesellschaft Berlin mbH, para. 36, ECJ, dec. of 14 May 2008, app. no C 109/07_Jonathan Pilato v. Jean Claude Bourgault, para. 24.

20 Dz.U. 2016, poz. 718 as am.

21 A statue from 30 August 2002 Law on proceedings before administrative courts (Journal of Laws 2018, item 1302 as am.).

22 E.g. a judge shall be disqualified in a case of a person related to him by blood or marriage, directly or collaterally, within the fourth degree of consanguinity (relationship by blood) or the second degree of affinity (relation by marriage). An example for disqualification caused by the attitude to a case is present when a judge was or still is an agent of one of the parties.

23 Constitutional Tribunal of Poland, dec. of 16 April 2015, app. no SK 66/13, OTK-A 2015/4/47.

24 Grabenwarter and Pabel (2016), p. 493.
} 
equality of arms and the right of access to a court. ${ }^{25}$ The sanction for a breach, by a court of the European Union, of its obligation under that provision to adjudicate on the cases before it within a reasonable time, must be an action for damages brought before the General Court, since such an action constitutes an effective remedy. ${ }^{26}$

A final, binding judgment is also of crucial importance. The judgment may not be altered by a non-judicial authority to the detriment of an individual party. ${ }^{27} \mathrm{~A}$ final judgment has a binding force, meaning that all public authorities and individuals are obliged to take into account the content of the judgment in future legal activities. The right to an effective remedy would be illusory if the binding force of a judgment could be only facultative for the court and the parties of the proceeding. In that situation the improvement of legal piece would be impossible. A principle of trust to a judicial system and the whole state will be disturbed. Parties of the proceeding could bring to a court new remedies which will be ineffective, because they will not lead to the end of the dispute. In that sense, the execution of a judgment must be regarded as an integral part of the effective remedy and a fair trial.

\section{Under what kind of circumstances can a remedy be evaluated as effective?}

The question about the effectiveness of a legal remedy is grounds for many disputes in doctrine and in jurisprudence. The answer to this question depends on understanding the concept of effectiveness in a legal system, in procedural law, especially in the system of legal remedies.

When is a remedy ineffective? ECJ answers that a remedy should not be illusory. Member States are responsible for ensuring that the basic rights are effectively protected in each case and, in particular, for ensuring compliance with the right to an effective remedy and to a fair hearing. ${ }^{28}$ The basic rights should be protected by procedural guarantees. A basis for them are concrete resolutions located and derived form the Article 47 of the Charter of Fundamental Rights of the European Union.

The effectiveness of a remedy manifests itself in the sense either of preventing the alleged violation or its continuation, or in providing adequate redress for any violation that had already occurred. ${ }^{29}$ In this sense, the effectiveness of a remedy does not depend on the certainty of a favorable outcome for the applicant. For this standard not only is access to a court significant, but also the effectiveness of the court's functions and procedural competences of the petitioner. ${ }^{30}$ In other words, the whole

\footnotetext{
25 ECJ, dec. of 30 June 2016, app. no C-205/15-Direcția Generală Regională a Finanțelor Publice Brașov v. Vasile Toma, Biroul Executorului Judecătoresc Horațiu-Vasile Cruduleci, para. 47.

26 ECJ, dec. of 14 September 2016, app. no C-519/15-P. Trafilerie Meridionali SpA v. European Commission, para. 65.

27 ECtHR, dec. of 19 April 1994, app. no 16034/90 — Van de Hurk v. The Netherlands, para. 45.

28 ECJ, dec. of 8 November 2016, app. no C 243/15, Lesoochranárske zoskupenie VLK v. Obvodný úrad Trenčín, para. 65.

29 ECtHR, dec. of 26 October 2000, app. no 30210/96-Kudła v. Poland, para. 158.

${ }^{30}$ Górski (2016), p. 39, Kułak-Krzysiak (2017), p. 128-129.
} 
proceeding should be effective not only form theoretical but above all from practical point of view.

A remedy is effective when the proceeding which is initiated by bringing it to the court fulfills the conditions from the second paragraph of Article 47. The court should have a possibility to examine all aspects of a case which are significant for the final outcome. This requirement is legible especially when the courts determine the cases only with cassation competence and when they could not present full evidence. This model of administrative judiciary was present in Austria until $1^{\text {st }}$ January $2014^{31}$ and is still present in Poland. ${ }^{32}$ According to Article 106 paragraph 3 of the Law on Proceedings Before Administrative Courts, an additional documentary proof could be conducted before an administrative court only when it is necessary to resolve substantial doubts and when it would not extend excessively the proceedings on the case. This means that an administrative court issue a judgment on the basis of files of the case collected by an administrative authority. ${ }^{33}$ If an administrative decision and proceeding before an authority is lawful, a court dismiss a complaint. If this decision in unlawful also in a sense of factual side, a court quash it or find it as invalid.

A court should have full jurisdiction to evaluate and determine a case. ${ }^{34}$ Effective judicial review must be able to cover the legality of the reasons for the contested decision. This is only a minimum standard for the remedy before an administrative court. $^{35}$ In special cases, connected e.g. with refugee proceeding, the standard of notification of the court's reasons to an administrative authority could be insufficient. The extent of the judicial review which is based only on evaluating the legality of an administrative decision could not safeguard an exhaustive examination of the expediency of the measure in question and for this reason was recognized as inadequate to the requirements of sufficiently effective protection. ${ }^{36}$

An example of such tendencies is directive 2013/32/EU. ${ }^{37}$ In Article 46 Member States are obligated to ensure that applicants have the right to an effective remedy before a court or tribunal, against decisions connected with international protection mentioned in this regulation. According to paragraph 3 of this article, Member States shall ensure that an effective remedy provides for a full and ex nunc examination of

\footnotetext{
31 Steiner (2013) p. 8-10, Sporrer (2013) p. 423-424.

32 The administrative courts in Poland control public administration. It means, that they can not supplement executive power in its functions. See more Hauser (2003), p. 147.

33 Radzikowski (2009), p. 51, Bińczyk and Kopacz, (2013), p. 126.

34 Półtorak (2013) p. 1220.

35 According to Article 5 a Recommendation Rec(2004)20 of the Committee of Ministers to Member States on the judicial review of administrative acts, a court should be competent at least to quash the administrative decision and if necessary to refer the case back to the administrative authority to rule a new decision that complies with the judgment.

36 ECJ, dec. of 24 April 2004, app. of C 482/01-Orfanopoulos v. Land Baden Württemberg, para. 113, ECJ, dec. of 2 June 2005, app. no C 136/03-Georg Dörr v. Sicherheitsdirektion für das Bundesland Kärnten, Ibrahim Ünal v. Sicherheitsdirektion für das Bundesland Vorarlberg, para. 52.

37 Directive 2013/32/EU of the European Parliament and of the Council of 26 June 2013 on common procedures for granting and withdrawing international protection (recast), Official Journal of the European Union L 180/60.
} 
both facts and points of law. From this regulation comes a demand to a full jurisdiction in cases from the area of granting and withdrawing international protection. It means that an administrative court should examine not only the normative aspects of a case, but also new facts. In other words, an independent court should be allowed to deal not only with points of law but also with facts. A remedy which commences a proceeding before court, limited only to a control of legality of an administrative act, for this regulation is regarded as ineffective.

The presented guaranties of an effective remedy does not mean that a legislator or even in a court practice can not be improved some restrictions for lodging or hearing remedies if there are concrete reasons for that. ${ }^{38}$ One of such reason could be linked with an effectiveness of a proceeding mostly from a perspective of a necessity to hear a case in reasonable time. For that reasons courts of higher instances are usually focused only on normative aspects of a case and remedies are limited to some of the most significant violations of law committed in a proceeding before a court of lower instance. This kind of limitations can not exclude a right to lodge a remedy and to hear a case.

\section{Poland and the right to an effective remedy}

The standard of the right to an effective remedy is fulfilled in all EU Member States differently. Each state has its own legal tradition, culture and experience. Therefore an interaction between European standards of law and domestic regulations is characteristic for each Member State. In this part of the paper will be presented selected interactions between European and Polish standards of the right to an effective remedy.

\subsection{Scope of jurisdiction of administrative courts in refugee and visa cases}

One of the interactions is connected with access to court in refugee and visa cases. According to Article 32 paragraph 3 of the Community Code on Visas, ${ }^{39}$ an applicant who has been refused a visa shall have the right to appeal. Appeals shall be conducted against the Member State that has taken the final decision on the application and in accordance with the national law of that Member State. This regulation remains in compliance with Article 5 paragraph 1 of the Polish Law on proceedings before administrative courts which excludes a competence of administrative courts relating to visas issued by consuls. ${ }^{40}$ In this legal order the Polish

\footnotetext{
38 Grabenwarter and Pabel (2016), p. 499.

39 Regulation (EC) No 810/2009 of the European Parliament and of the Council of 13 July 2009 establishing a Community Code on Visas, Official Journal of the European Union from 15 September 2009, L 243/1.

${ }^{40}$ Except for visas issued to an alien being a family member of a national of the European Union member state, family member of a national of a member state of the European Free Trade Association-a party to European Economic Area Agreement or family member of a national of the Swiss Confederation, within the meaning of Article 2 (4) of the Act of 14 July 2006 on the entry into, residence in and exit from the Republic of Poland of nationals of the European Member States and their family members.
} 
Supreme Administrative Court formulated a question to ECJ if Article 32 paragraph 3 Visa Code should be interpreted in a way that a member state has an obligation to guarantee an effective remedy before a court in such cases. ${ }^{41}$

Answering this question ECJ stated, that Article 32 paragraph 3 of the Visa Code, read in the light of Article 47 of the Charter, must be interpreted as meaning that it requires Member States to provide for an appeal procedure against decisions refusing visas, the procedural rules for which are a matter for the legal order of each Member State in accordance with the principles of equivalence and effectiveness. Those proceedings must, at a certain stage of the proceedings, guarantee a judicial appeal. $^{42}$ The judgment of ECJ affected the Polish legislature in a sense, that the scope of jurisdiction of Polish administrative courts was broadened on a control over refusals of a visa, revocation or annulment of Schengen visas and the consul's activity in the above-mentioned scope. ${ }^{43}$ In a written explanation of the amendment was expressly stated, that the aim of the state is an adjustment of the existed regulation to the ECJ judgment in the case El Hassani and granting the right to an effective legal remedy before a court from decisions on refusal of a visa, revocation or annulment of Schengen visas. ${ }^{44}$

\subsection{Hearing a case by a court in a reasonable time}

Second interaction is connected with one of the special rights of an effective remedy, namely with the right to a hearing within a reasonable time. In the case of Andrzej Kudła ${ }^{45}$ who was accused of fraud and forgery and therefore detained on remand, ECtHR took note of "the important danger" that exists for the rule of law within national legal orders when "excessive delays in the administration of justice" occur with respect to which litigants have no domestic remedy. The right of an individual to a trial within a reasonable time will, according to ECtHR, be less effective if there exists no opportunity to submit the Convention claim first to a national authority. The correct interpretation of Article 13 is that provision guarantees an effective remedy before a national authority for an alleged breach of the requirement under Article $6 \S 1$ to hear a case within a reasonable time.

\footnotetext{
41 An order of the Supreme Administrative Court in Warsaw from 28 July 2016, app. no II OSK $1346 / 16$.

42 ECJ, dec. of 13 December 2017, app. no C 403/16, Soufiane El Hassani v. Minister Spraw Zagranicznych, para. 42.

43 A statue from 9 November 2018 about an amendment of the Law about proceeding before administrative courts (Journal of Laws 2019, item 11).

44 A written explanation of a project of a statue from 9 November 2018 about an amendment of the Law about proceeding before administrative courts; https://www.sejm.gov.p1/Sejm8.nsf/druk.xsp?nr=2908; access on 6 July 2019.

45 ECtHR, dec. of 26 October 2000, app. no 30210/96-Kudła v. Poland, para. 150-156.
} 
As a result of this judgment, a special statue ${ }^{46}$ was passed where individuals obtained a new remedy against unjustified length of a proceeding before courts of all branches and administrative organs. In Article 2 paragraph 2 criteria for too long proceeding are distinguished. These are punctuality of a court's activities, the degree of complexity of a case, significance of the case for the parties and procedural behavior of the party who complains the length of proceeding. In a judgment a court may give recommendations to the court which leads the case in question to avoid lengthening the proceeding in the future. The claimant may obtain also a compensation from $2000 \mathrm{zł}$ to $20,000 \mathrm{zł}$.

The right to an effective remedy could create a new interpretation of existing remedies (a doctrine of no new remedies) or a necessity to establish such a remedy to achieve a minimum standard for the protection of EU law (a doctrine of minimum new remedies). ${ }^{47}$ The above mentioned judgment is an example of the second possibility.

\subsection{Legal aid and cassation appeal in judicial administrative proceeding}

A third interaction is linked with the amendment of Article 177 of the Law on proceedings before administrative courts, which was affected by the jurisprudence of ECtHR. In the above mentioned Article is regulated a period of time for lodging a cassation appeal to the Supreme Administrative Court from a judgment of a voivodship administrative court. The cassation appeal is an ordinary remedy in the Polish court-administrative procedure which should be drawn by a lawyer or legal counsel. In practice, a party who wants to lodge this remedy and was not previously represented by a lawyer, in time for bringing the cassation appeal to the court, usually submit a motion for appointment of a lawyer, legal counsel, tax adviser or patent agent. A decision about granting legal aid usually was taken when the term for lodging a cassation appeal is expired. In this situation the granted lawyer had to apply for the reinstatement of the time limit. Though for lodging a cassation appeal a party has 30 days, a motion for reinstatement of the time limit has to be lodged within 7 days from the date of termination of the reason for failure to comply with the time limit. Additionally, the procedural regulation does not provide consequences of the refusal of lawyer in preparation a cassation appeal for the party of a proceeding.

A lack of this regulation was negatively evaluated by the ECtHR who stated, that legislative uncertainty or arising from practices applied by the authorities causes a violation of the individual's right of access to court on account of the absence of clear rules governing the consequences of the legal-aid lawyer's refusal occurring

\footnotetext{
46 A statue from 17 July 2004 about the complaint for breach of the right to hear the case in preparatory proceedings conducted or supervised by the prosecutor and the judicial proceedings without undue delay, Official journal 2016, poz. 1259 as am.

47 ECJ, dec. of 19 June 1990, app. no C 213/89 - The Queen v. Secretary of State for Transport, ex parte Factortame Ltd and others, para. 20, Baran (2014) p. 110-111.
} 
after the deadline for lodging a cassation appeal which had already expired. ${ }^{48}$ In a final result, the Article 177 of the Law on Proceedings before administrative courts was in 2015 specified. ${ }^{49}$ Currently time limit is clearly regulated for lodging a cassation appeal which is initiated after appointment of a lawyer in a concrete case. Time for lodging this remedy is initiated for an individual ex novo if a lawyer refuse to prepare a cassation complaint.

\section{Conclusions}

The right to an effective remedy is one of the most significant guarantees which ensure the rule of law. Therefore it is developed in many judgments of ECJ and ECtHR. Although the judgments are devoted to special cases, the European courts give general standards of the right in justifications. The standards should be helpful for national legislators to create their own court's remedies.

For the court as an authority obliged to resolve effective remedies the standards are: statutory rules about appointment of the judges, length of service and the grounds for abstention, rejection and dismissal of its members, permanence in functioning, organizational independence from all parties of a dispute, impartiality and competence in adjudication. Only when all of the above mentioned standards are fulfilled it is possible to evaluate a state power as a court.

An effective remedy should prevent the alleged violation or its continuation, or provide adequate redress for any violation that had already occurred. A remedy is effective when the proceeding which is initiated by bringing it to the court fulfills the conditions from the second paragraph of Article 47. Under these circumstances an individual has a real possibility to defend their rights and present their statements in a concrete case before an independent and impartial tribunal. It is worth mentioning that a right to a trial within a reasonable time is only one component of the effectiveness. Currently many European countries pay special attention on this aspect of the right to an effective remedy. It is truth that a proceeding before a court should reach completion in reasonable time. This component has not a crucial significance in evaluation a remedy as effective. A remedy should fulfill all above mentioned requirements to be evaluated as effective.

The right to an effective remedy remains in an interaction with domestic regulations of all EU Member States. In comparison with the Polish system of law three aspects of the right are worth mentioning. The first aspect is connected with the right to an effective remedy derived from Article 32 paragraph 3 Visa Code and Article 5 point 1 Polish Law on Proceedings Before Administrative Courts. This question is under proof of ECJ. The second presented aspect was connected with an adjudication in a reasonable time. The structural solution was issued by ECJ in 2000. Nowadays in many countries

\footnotetext{
${ }^{48}$ ECtHR, dec. of 14 October 2010, app. no 29342/06 - Słubicka v. Poland, para. 47. See also ECtHR, dec. of 19 May 2009, app. no 18353/03 - Kulikowski v. Poland, para. 58-59.

49 A statue from 9 April 2015 about the amendment of the Law on proceedings before administrative courts, Official journal 2015, poz. 658 as am.
} 
there are special measures to question unjustified length of a proceeding before courts. The third interaction appeared between the jurisprudence of ECtHR and the regulation in judicial administrative proceeding about legal aid and time for lodging a cassation appeal. In a final result Polish regulation is more detailed in the area of granting legal aid during the course of time for lodging a cassation appeal.

The interactions cause to raise the standards of the effectiveness of the remedies in national proceedings. Communities who are EU-Members are obliged to take into consideration all requirements of the right to an effective remedy derived from jurisprudence ECJ and ECtHR. Nevertheless the interaction has two sides. The jurisprudence of ECJ and ECtHR is inspired by the legal orders and judgments of national courts. The individual cases are basis for the European courts to formulate general principles of EU-law. In the interactions the active role of two sides is indispensable. Both European and national courts, legislators and public authorities build one common system of European law.

Open Access This article is distributed under the terms of the Creative Commons Attribution 4.0 International License (http://creativecommons.org/licenses/by/4.0/), which permits unrestricted use, distribution, and reproduction in any medium, provided you give appropriate credit to the original author(s) and the source, provide a link to the Creative Commons license, and indicate if changes were made.

\section{References}

Baran M (2014) Stosowanie z urzędu prawa Unii Europejskiej przez sądy krajowe. Lex a Wolters Kluwer business, Warszawa

Bińczyk A, Kopacz M (2013) O znaczeniu akt sprawy dla wyniku sądowo administracyjnej kontroli działalności administracji publicznej, $\mathrm{Nb} 3, \mathrm{p} 126$

Garoupa N, Ginsburg T (2009) Guarding the guardians: judicial councils and judicial independence. Am J Comp Law 57(1):103-134

Górski M (2016) Prawo do skutecznego środka prawnego w art. 47 Karty Praw Podstawowych UE-znaczenie i deficyty, Europejski Przegląd Sądowy Nb 8

Grabenwarter C, Pabel K (2016) Europäische Menschenrechtskonvention, Mûnchen

Hauser R (2003) Konstytucyjny model polskiego sądownictwa administracyjnego. In: Stelmasiak J, Niczyporuk J, Fundowicz S (eds) Polski model sądownictwa administracyjnego, Lublin

Kosař D (2017) Politics of judicial independence and judicial accountability in Czechia: bargaining in the shadow of the law between court presidents and the ministry of justice. Eur Const Law Rev 13(1):96-123

Kułak-Krzysiak K (2017) Efektywność jako wartość w postępowaniu sądowo administracyjnym. In: Zimmermann J (ed) Aksjologia prawa administracyjnego. Tom II, Warszawa

Papier HJ (2001) Die richterliche Unabhängigkeit und ihre Schranken, Neue Juristische Wochenschrift $\mathrm{Nb} 15$

Półtorak N (2013) Komentarz do art. 47. In: Wróbel A (ed) Karta praw podstawowych UE. Komentarz, Warszawa

Radzikowski K (2009) Orzekanie przez sąd administracyjny na podstawie akt sprawy, Zeszyty Naukowe Sądownictwa administracyjnego $\mathrm{Nb} 2$, p 51

Sporrer A (2013) Die Verwaltungsgerichtsbarkeit kurz vor ihrer Einführung, Zeitschrift für Verkehrsrecht $\mathrm{Nb} 12$

Steiner W (2013) Das Projet "zweistufige Verwaltungsgerichtsbarkeit”. In: Janko A, Leeb D (eds) Verwaltungsgerichtsbarkeit erster Instanz. Entstehung und verfassungsrechtliche Grundlagen, Wien

Voßkuhle A, Sydow G (2002) Die demokratische Legitimation des Richters, Juristen Zeitung Nb 14 